\title{
СУЧАСНИЙ СТАН РОЗПОВСЮДЖЕННЯ ВІДКЛАДЕНЬ ОЖЕЛЕДІ НА ТЕРИТОРІЇ УКРАЇНИ ВЗИМКУ ТА ОКРЕМІ МІСЯЦІ ПЕРЕХІДНИХ СЕЗОНІВ РОКУ ПРОТЯГОМ 2011-2019 РР. ПОРІВНЯНО 3 1981-2010 РР. (ЗА СПОСТЕРЕЖЕННЯМИ НА СТАНДАРТНОМУ ОЖЕЛЕДНОМУ СТАНКУ)
}

\section{Пясецька С. І., Гребенюк Н. П.}

\section{ВСТУП}

Відкладення ожеледі на території України є типовим явищем для місяців холодного та перехідних сезонів року. Найбільш часто сприятливі умови для їх виникнення спостерігаються у зимові місяці за просування на територію України циклонів із Свропи та підвищення температури до незначних від'ємних та додатних температур повітря, випадання помірних опадів або опадів у вигляді мряки, а іноді за рахунок осідання вологи 3 потужних крупнокрапельних ткманів. Така ситуація $\epsilon$ найбільш сприятливою для відкладень ожеледі на території країни, зокрема масового характеру. Відкладення ожеледі відносять до несприятливих погодних явищ, які створюють відповідні незручності та перешкоджають безперебійній роботі низки галузей господарства, які $\epsilon$ найбільш залежними від ожеледо-паморозевих відкладень, особливо коли ті сягають небезпечних або стихійних значень.

Дослідженнями ожеледо-паморозевих відкладень, зокрема ожеледі на території України, займалась низка вчених-кліматологів, зокрема О.М. Раєвський, який розробив схему типізації ландшафтів, будова яких сприяє виникненню таких відкладень. Досвід та результати робіт О.М. Раєвського було використано у низці робіт інших дослідників, зокрема колективом авторів під керівництвом В.М. Бабіченко ${ }^{1}$ та низкою інших авторів ${ }^{23}$, які продовжили дослідження розповсюдження окремих видів ожеледо-паморозевих відкладень на території України на сучасному на той час етапі розвитку кліматичної системи в Україні.

${ }^{1}$ Климат Украины / под ред. Г.Ф. Приходько, А.В. Ткаченко, В.Н. Бабиченко. Ленинград : Гидрометеоиздат, 1967. 413 с.

2 Природа Украинской ССР. Климат / под ред. К.Т. Логвинова, М.И. Щербаня. Киев : Наукова думка, 1984. 231 с.

${ }^{3}$ Клімат України / за ред. В.М. Ліпінського, В.А. Дячука, В.М. Бабіченко. Київ : вид-во Раєвського, 2003. 343 с. 
Паралельно з цими роботами було проведено низку робіт із виявлення осередків найбільш небезпечних ожеледо-паморозевих відкладень у межах окремих регіонів території України ${ }^{4}$. Найбільш докладними 3 них були монографії, які виконано у 1991 р. ${ }^{5}$ та у 2006 p..$^{6}$ у УкрГМІ ДСНС України та НАН України під керівництвом В.М. Бабіченко. Проте у цих публікаціях не було проведено порівняння поточних періодів спостережень за окремими явищами 3 періодами, які їм передували, та відносно 30-річних періодів, зокрема стандартних кіліматологічних норм, тому не визначено тенденції, які відбуваються у змінах клімату стосовно окремих його елементів на території України. Окрема частина цієї роботи була опублікована автором у колективній монографії, яка була видана у 2020 р. за сприяння Куявського університету у Влоцлавеку (Польща) ${ }^{7}$, тому нагальною необхідністю $є$ продовження таких робіт для з'ясування ходу змін у кліматичній системі окремих територій внаслідок глобального потепління.

Для визначення сучасних тенденцій у розповсюдженні відкладень ожеледі на території України на сучасному етапі зміни клімату протягом 2011-2019 рр. проведено порівняння середньої кількісті випадків таких відкладень за цей період відносно рекомендованого ВМО 30-річчя протягом 1981-2010 pp. Необхідність такого порівняння визначено тим, що протягом останнього часу відбулися суттєві зміни у сучасній кліматичній системі внаслідок триваючого потепління. Період 1981-2010 pp. був запропонований ВМО з огляду на темпи зміни клімату у світі та відображає більш осучаснений період для проведення порівняння з іншими періодами.

Матеріалами для опрацювання були дані таблиць спостережень за ожеледо-паморозевими відкладеннями на дротах стандартного ожеледного станка, які подано у Метеорологічному щомісячнику (Вип. 10., Ч. II, Україна), що знаходяться у Державному галузевому архіві Центральної геофізичної обсерваторії ім. Бориса Срезневського

4 Опасные явления погоды на Украине / под ред. К.Т. Логвинова. Tpyды УкрГИГМИ. 1972. Вып. 110. 235 с.

5 Стихийные метеорологические явления на Украине и Молдавии / под ред. В.Н. Бабиченко. Ленинград : Гидроииетеоиздат, 1991. 223 с.

${ }^{6}$ Стихійні метеорологічні явища на території України за останнє двадцятиріччя (1986-2005 рр.) / за ред. В.М. Ліпінського, В.І. Осадчого, В.М. Бабіченко. Київ : Ніка-Центр, 2006. 311 с.

${ }^{7}$ Пясецька C.I. Тенденції в поширенні відкладень ожеледі на території України протягом 1991-2000 pp., 2001-2010 pр. на сучасному етапі зміни клімату (20112019 рр.) у місяці холодного періоду року та окремі місяці перехідних сезонів : колективна монографія. Scientific developments of Ukraine and EU in the area of natural sciences. P. 2. Wloclavek. Poland, 2020. C. 631-650. DOI: https://doi. org/10/30525/978-9934-588-73-0/2/13. 
(м. Київ). Порівняння було здійснено для зимових місяців та місяців перехідних сезонів року, а саме березня, квітня, жовтня та листопада. Виділено загальні осередки додатних та від'ємних відхилень середньої кількості випадків відкладень ожеледі протягом останніх 9 років (20112019 рр.) відносно 30-річного періоду 1981-2010 рр. по окремих регіонах України та визначено окремі більш уособлені осередки таких відкладень, які чітко виокремлюються на загальному фоні. Це вказало на певні тенденції у розподілі відкладень ожеледі на території України на сучасному етапі зміни клімату у найбільш значущих для цього явища місяцях. Результати проведеного порівняння відображено на рис. 1. На жаль, інформації щодо сучасного стану розповсюдження відкладень ожеледі на території АР Крим для порівняння 3 періодом 1981-2010 pр. недостатньо внаслідок відсутності інформації із січня 2015 р. внаслідок незаконної анексії Криму РФ. Крім того, приблизною $\epsilon$ тенденція у змінах в розповсюдженні випадків відкладень ожеледі на частині території Донецького регіону, яка не підконтрольна Україні.

\section{1. Тенденції у розповсюдженні відкладень ожеледі на території України протягом 2011-2019 рр. у зимові місяці порівняно з 1981-2010 рр.}

Січень. Протягом 2011-2019 рр. відносно 1981-2010 рр. на більшій частині території України переважали додатні відхилення середньої кількості випадків відкладень ожеледі. Так, на території західних та північно-західних областей України спостерігався значний осередок таких відхилень, який охоплював значні частини територій областей, а саме Житомирської, Волинської (більшу частину за винятком території поблизу Луцька), Тернопільської, Хмельницької, Чернівецької, ІваноФранківської, частину Львівщини поблизу Львова та на ії південнозахідну частину. Основні центри додатних відхилень середньої кількості випадків відкладень ожеледі, які суттєво виділялись на території цих областей та перевищували значення $+0,6$, знаходились на півночі Волинської області в районі Любешова $(+1,4)$ та Світязя $(+0,6)$, Рівненської області в районі Сарн $(+0,6)$, на півночі та заході Житомирської області на території Овручсько-Словечанського кряжу $($ Олевськ $(+1,5)$, Овруч $(+1,0)$, Новоград-Волинський $(+0,8))$. У західних областях виділялись центри значних додатних відхилень середньої кількості випадків відкладень ожеледі на території північно-західної частини Львівщини в районі Кам'янки Бузької $(+0,8)$, Бродів $(+0,6)$ та самого Львова $(+1,2)$. У Хмельницькій та Тернопільській областях основні, найбільш значні центри таких відхилень спостерігались на півночі Хмельниччини у Шепетівці та Ямполі $(+1,2)$, а також на 
Тернопільщині в районі Тернополя $(+1,4)$, особливо Чорткова $(+2,5)$. Дещо менші центри таких відхилень спостерігалися в районі Хмельницького $(+0,7)$, Нової Ушиці $(+0,9)$ та Кам'янця Подільського $(+0,6)$. Цей значний осередок, який пов'язаний із розповсюдженням цих відкхилень середньої кількості випадків відкладень ожеледі на території Хмельниччини та Тернопільщини продовжується на території Івано-Франківської та Чернівецької областей 3 найбільш помітними центрами в районі Долини та Яремче $(+0,8)$, Чернівців $(+1,7)$ та Селятина $(+0,8)$. На Закарпатті найбільш помітний осередок додатних відхилень середньої кількості випадків відкладень ожеледі розташований на північно-західній частині області в районі Нижніх Воріт $(+0,8)$ (рис. 1). Осередок від'ємних відхилень середньої кількості випадків відкладення ожеледі розташований на південному заході Закарпаття з центром в районі Берегового $(-1,1)$. Майже не змінилась середня кількість випадків відкладень ожеледі на південному сході Волинської області в районі Луцька та в районі Дубно (Рівнеська область). Така ж ситуація спостерігається на території частини Львівської області в районі Яворова, Мостиськи, Самбора та Дрогобича, а також на значній частині території Закарпаття.

У північному та північно-східному регіонах розповсюдження осередку додатних відхиленеь спостерігалось на території північнозахідної частини Київщини, півночі та центрі Чернігівщини, сході Сумщини, півночі та заходу Харківщини. Осередок додатних відхилень середньої кількості випадків відкладень ожеледі на території північнозахідної частини Київської області пов'язаний із розповсюдженням таких відхилень на території північно-західних областей, таких як Житомирщина. Помітний центр таких відхилень розташований у районі Вишгороду $(+0,6)$. Осередок на півночі Чернігівщини та на території північно-східних областей (Сумщина, Харківщина) займає велику площу та продовжується у своїй південній частині на території областей центрального регіону, а саме Полтавщини, Черкащини, Кіровоградщини, Дніпропетровщини, а також пов'язаний на сході 3 північчю Луганщини та західною частиною Донеччини й Запоріжжям. На території кожної області, які входять до північного та північносхідного регіонів, відокремлюються найбільш виразні осередки додатних відхилень середньої кількості випадків відкладень ожеледі протягом 2011-2019 рр. відносно 1981-2010рр. Найбільший осередок таких відкладень на території Чернігівщини знаходиться в районі Семенівки $(+1,3)$, Сновську $(+1,6)$, особливо в районі Покошичів $(+1,9)$. Крім того, цей осередок розповсюдився в район Чернігова $(+0,7)$, Ніжина $(+1,3)$ та Прилук $(+0,9)$. На території Сумської області найбільш значні осередки додатних відхилень середньої кількості випадків знаходяться у Глухові $(+0,9)$ та Сумах $(+1,0)$. Майже не 
змінилась середня кількість випадків відкладень ожеледі в районі Конотопу. Значний осередок додатних відхилень на північному сході країни розташований на території Харківщини, має декілька помітних центрів. Особливо помітний центр таких відхилень знаходиться на заході області в районі Коломаку $(+2,3)$ та розповсюджується у бік Золочева $(+1,4)$, Богодухова $(+1,3)$ та Харкова $(+1,2)$ на північ та північний схід, а також на південний захід у бік Краснограду $(+1,2)$. На північному заході області також виокремлюється помітний осередок додатних відхилень в районі Великого Бурлуку $(+1,7)$, Куп'янську $(+1,2)$ та Слобожанського $(+1,0)$ (рис. 1$)$. Осередок від'ємних відхилень знаходиться на південному заході та півдні Київщини, який розповсюджується на північ на північний захід Черкаської області у бік Жашкова та Звенігородки. Центр такого осередку знаходиться в районі Білої Церви $(-0,6)$ та у Миронівці $(-0,6)$. Крім того, на території східної частини Київщини середня кількість випадків відкладень ожеледі майже не змінилась (у Баришівці та Яготині).
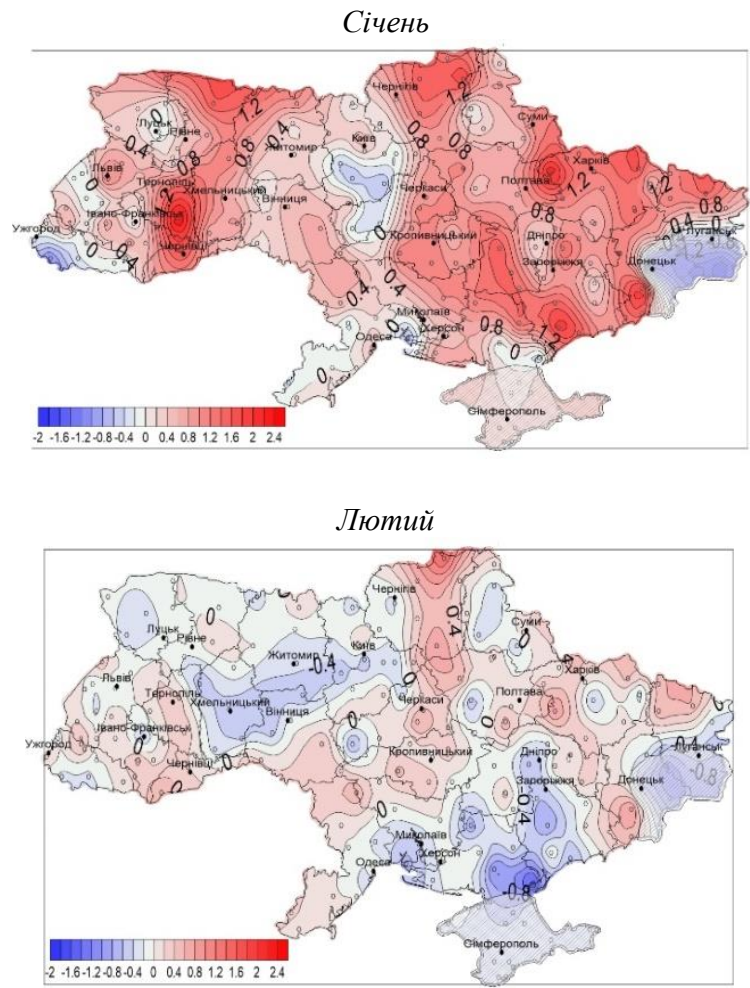


\section{Березень}

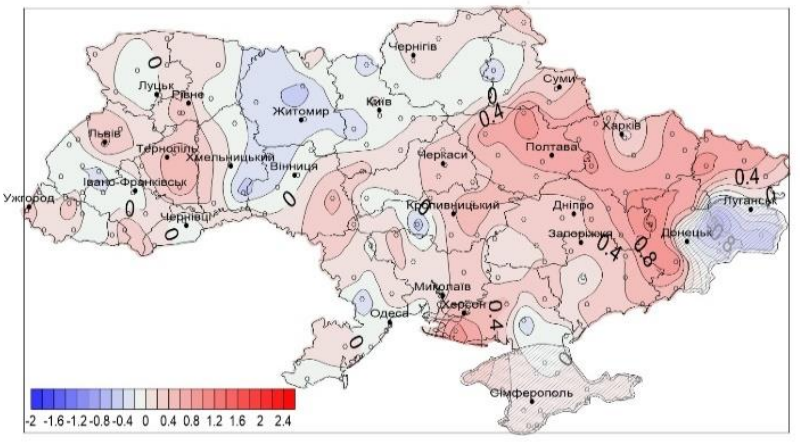

Квітень

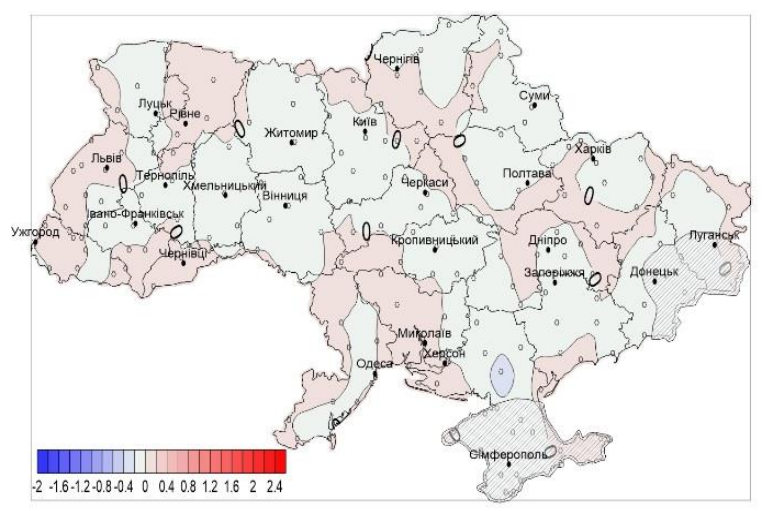

Жовтень

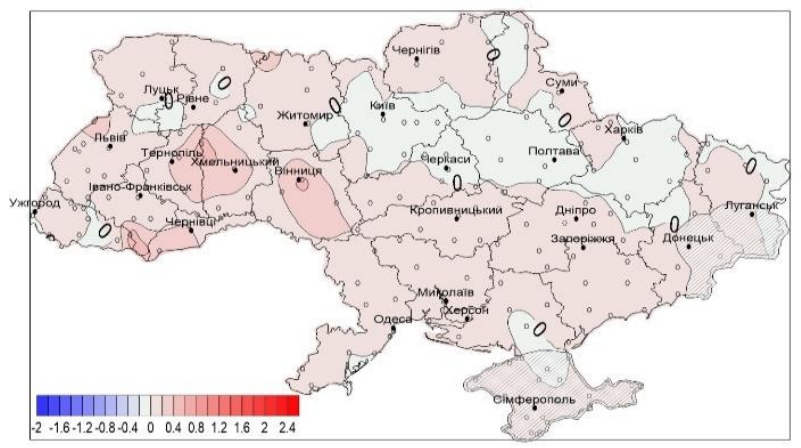




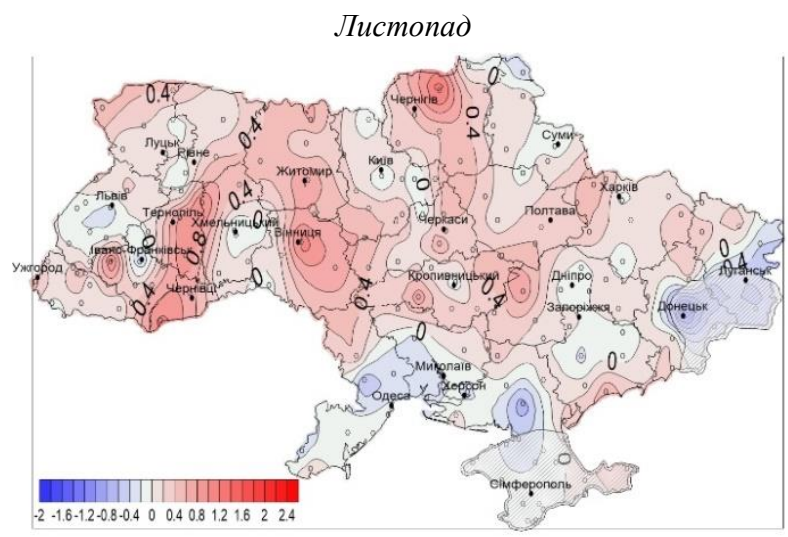

Грудень

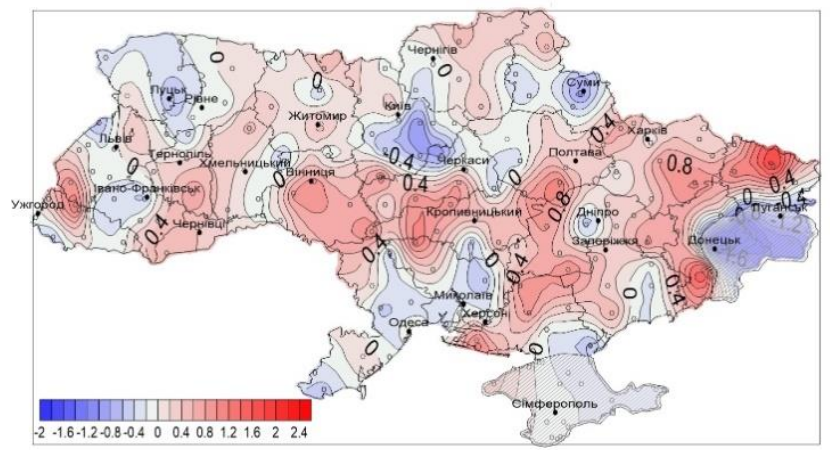

Рис. 1 Відхилення середньої кількісті випадків відкладень ожеледі за місяці холодного періоду року та у окремі місяці перехідних сезонів у 2011-2019 рр. порівняно із періодом 1981-2010 pp.

На сході країни розповсюдження додатних відхилень спостерігалось на півночі та заході Луганської області, заході та півдні Донецької області. Цей осередок пов'язаний із загальним осередком розповсюдження додатних відхилень, який займає області України 3 півночі (Чернігівщина), охоплюючи північний схід, центр та південний схід країни. Найбільш помітними виокремленими осередками додатних відхилень середньої кількості випадків відкладень ожеледі є осередки на півночі Луганщини з центром в районі Новопскова $(+1,5)$, Сватового $(+1,2)$, Троїцького $(+1,0)$ та Біловодська $(+0,7)$. На Донеччині найбільш помітні центри значних додатних відхилень знаходяться в районі 
Покровського $(+1,3)$, Бахмута (Артемівська) $(+0,7)$, особливо на півдні області в районі Волновахи $(+2,1)$ та Маріуполя $(+1,5)$. Осередок від'ємних відхилень знаходиться у східній частині обох областей та охоплює територію у напрямку з півночі на південь від Луганська та Дар'ївки до Дебальцевого, Донецька та Амвросіївки. У цих пунктах спостерігаються найменші з від'ємних відхилень (Дар'ївка має -1,9, Луганськ має -0,9, Дебальцеве має -1,3, Донецьк має -1,7, Амвросіївка має -1,5). На жаль, більш точної інформації по окремих районах східного регіону немає з огляду на зону проведення АТО в цьому регіоні. У центральному регіоні спостерігались два значних осередка додатних відхилень середньої кількості випадків відкладень ожеледі 2011-2019 рр. відносно 1981-2010 рр. Один з них розташований на території Вінниччини та пов'язаний із осередком на території Житомирщини та Хмельниччини. Південна частина цього осередку простягається на території Одещини. У межах Вінницької області значення цих відхилень не перевищували $+0,6 \ldots+0,7$ (Вінниця, Гайсин). Встановлено осередки, де середні значення кількості випадків відкладень ожеледі майже не змінились, а саме північний захід Вінниччини в районі Хмільника та на півдні області поблизу МогиліваПодольського. Інший осередок охоплює території Черкащини, Кіровоградщини, Полтавщини та Дніпропетровщини. Найбільш помітні осередки додатних відхилень спостерігаються у східній частині Черкаської області в районі Чигирина $(+1,1)$, Сміли $(+1,2)$, Золотоноши $(+0,9)$ та Черкас $(+0,8)$. Розповсюдження значних додатних відхилень середньої кількості випадків відкладень ожеледі простягається на територію Кіровоградської області, де вони набувають ще більшого поширення. Так, на Кіровоградщині найбільш значні додатні відхилення займають центральну іiі частину 3 півночі на південь від Світловодська до Бобринця та Долинської. Найбільші їх значення зафіксовано у Світловодську, Помічній та Бобринці $(+1,2)$, Новомиргороді $(+0,8)$, Гайвороні $(+0,6)$ та Долинській $(+0,9)$. На Полтавщині центри значних додатних відхилень розташовані на лівобережжі області в районі Гадяча $(+0,7)$, Лубен $(+1,1)$, Полтави $(+0,7)$ та Кобеляк $(+0,8)$. На Дніпропетровщині основні значні осередки додатних відхилень розташовані на правобережжі в районі від Комісарівки $(+1,6)$ в напрямку на південь в район Лошкарівки $(+1,4)$ та Кривого Рогу $(+1,0)$, а на лівобережжі - в районі Павлограду $(+1,0)$, Синельнікового $(+1,5)$ та Чаплиного $(+0,7)$. Незначні зміни у кількості відкладень ожеледі відбулись у Дніпрі. Незначні від'ємні відхилення спостерігались на території західної частини Черкаської області та на північному заході Кіровоградської області. 
На півдні країни значні осередки додатних відхилень спостерігались на півночі Одеської області з центрами в районі Любашвки $(+0,7)$ та Затишшя $(+0,6)$. Цей осередок був південною частиною осередку, який розташований у Вінницькій області. Майже не змінилась середня кількість випадків відкладень ожеледі на території південно-західної частини Одеської області. Інший осередок розташований на північному сході Миколаївщини 3 центром у Баштанці $(+1,0)$. На півдні Миколаївщини середня кількість випадків відкладень ожеледі майже не змінилась. Осередок значних додатних відхилень на північному сході та сході Миколаївської області пов'язаний із осередками таких відхилень у Кіровоградській та Дніпропетровській областях на півночі та сході. У поруч розташованій Херсонській області поле додатних відхилень спостерігається на сході, центрі та півдні. Найбільш значні відхилення відзначено у Великій Олександрівці $(+1,2)$ та Нижніх Сірогозах $(+1,4)$, дещо менші - у Новій Каховці $(+0,6)$, Бехтерах $(+0,8)$ та Хорлах $(+0,7)$. На Запоріжжі основний осередок розповсюдження додатних відхилень знаходиться на південному заході області в районі Мелітополя $(+2,0)$, Пришибу $(+1,5)$ та Ботієвого $(+1,6)$ а також Бердянська $(+0,8)$.

Лютий. У 2011-2019 pp. відносно 1981-2010 pp. на території північно-західних та західних областей спостерігалась низка осередків додатних відхилень середньої кількості випадків відкладень ожеледі, незначні за територією та інтенсивністю такі осередки спостерігались на території Житомирської, Рівненської та Львівської областей в районі Овруча, Рівного, Рави-Руської. Відхилення у цих осередках не перевищували $+0,2 \ldots+0,4$. Інший осередок, найбільший, знаходиться на території Тернопільської, Івано-Франківської, Чернівецької та Закарпатської областей. Здебільшого додатні відхилення у цьому осередку не перевищують $+0,4 \ldots+0,5$, проте у Селятині (Чернівецька область) та Нижніх Воротах (Закарпаття) додатне відхилення становить $+0,6$. Малопотужні осередки від'ємних відхилень середньої кількості випадків відкладень ожеледі $(-0,2 \ldots-0,3)$ спостерігаються на півночі Житомирщини (Олевськ), Волині в районі Ковеля, ВолодимирВолинського, Луцька. Подібні осередки зустрічаються на півдні Львівщини у Дрогобичі та півдні Закарпаття в районі Берегового й Хуста. Найбільший за площею осередок від'ємних відхилень середньої кількості випадків відкладень ожеледі спостерігався на території Хмельницької та півдні Житомирської областей. Крім того, він поширювався на північно-західну частину Вінничини, а на сході переходив на територію півдня Київщини. Найнижчі величини від'ємних відхилень не перевищують значень -0,4, проте у Ямполі (Хмельниччина) від’ємне відхилення становило -0,6 (рис. 1). 
На півночі та північному сході країни осередки додатних відхилень середньої кількості випадків відкладень ожеледі протягом 2011-2019 рр. відносно 1981-2010 рр. спостерігаються на території північно-східної частини Київщини (Вишгород має $+0,3)$, півночі, центру та півдня Чернігівської області, сходу Сумської області, півночі та заходу Харківської області. Найбільші значення додатних відхилень спостерігались на півночі Чернігівщини в районі Семенівки $(+1,5)$, Сновська $(+0,6)$ та Прилук $(+0,8)$. Ця частина осередку продовжується в бік півночі Полтавщини, Черкащини та Кіровоградщини. На Сумщині значення додатних відхилень не перевищували $+0,3$. На Харківщині найбільші значення додатних відхилень середньої кількості випадків відкладень ожеледі спостерігались на півночі та заході області в районі Золочева та Богодухова $(+0,6)$, а також Краснограду $(+0,9)$. Помітний осередок таких відхилень відзначено в районі Великого Бурлуку $(+0,5)$. На решті території цих областей значення додатних відхилень не перевищувало $+0,4$. Осередки від'ємних відхилень середньої кількості випадків відкладень ожеледі спостерігались на півдні Київщини 3 центрами у Києві та Фастові $(-0,6)$, поблизу Чернігова, на Сумщині (Глухів, Конотоп, Лебедин). Ці осередки були незначними за інтенсивністю (до -0,4). На Харківщині помічено локальні осередки від'ємних відхилень у районі Комсомольського та Куп'янська (-0,5 та 0,4 відповідно). На решті території вищезгаданих областей середня кількість випадків відкладень ожеледі майже не змінилась.

На сході країни у Луганській та Донецькій областях спостерігаються осередки додатних відхилень на півночі Луганської області в районі Троїцького $(+0,5)$, Новопскова $(+0,6)$, а також на півдні Донеччини у Волновасі $(+0,9)$. Осередок від'ємних відхилень охоплює південну частину Луганщини та східні частину Донеччини. Найнижчі значення таких відхилень відзначено у Дар'ївці $(-0,9)$, а також у Дебальцевому $(-1,2)$, Донецьку $(-0,7)$ та Амвросіївці $(-1,0)$. Ця інформація орієнтовна внаслідок відсутності даних щодо цієї території з 2014-2015 рр. внаслідок АТО.

У центрі країни осередки додатних відхилень розташовані у декількох областях. Найбільший осередок таких відхилень розташований на території Вінницької, Черкаської, Кіровоградської, Полтавської та Дніпропетровської областей. Західна частина цього осередку знаходиться у південній частині Вінниччини на південь від Гайсина. Цей осередок має своє продовження на півночі Одеської області. Значення додатних відхилень загалом не перевищувало $+0,3 \ldots+0,4$. На Черкащині найбільш помітний осередок таких відхилень спостерігався у Смілі $(+0,7)$, а на Кіровоградщині - в районі Помічної $(+0,5)$. На території Полтавщини такий осередок відзначено в районі Лубен та Кобеляк 
$(+0,6)$. На Дніпропетровщині осередок додатних відхилень середньої кількості випадків відкладень ожеледі знаходиться на лівобережжі області в районі Синельнікового, Лошкарівки та Чаплиного, а також поєднується на півночі з ареалом розповсюдження додатних відхилень на території півдня Харківської області, де значення додатних відхилень незначні i перебувають у межах $+0,2 \ldots+0,3$. Осередки від'ємних відхилень спостерігаються в низці областей, а саме на півночі Вінниччини в районі Білопілля та Хмільника $(-0,6)$, півночі та заході Черкащини в районі Канева $(-0,4)$ та в районі Умані $(-0,7)$. На території Полтавщини осередок від'ємних відхилень знаходиться в районі Веселого Подолу $(-0,6)$. На Дніпропетровщині осередок від’ємних відкладень займає центральну частину області та простягається з півночі на південь у район Запорізької області. Здебільшого значення від'ємних відхилень у цьому осередку становили $-0,1 \ldots-0,2$, а найнижчі значення $(-0,7)$ зафіксовано у Дніпрі.

На сході України, а саме на Луганщині та Донеччині, осередки додатних відхилень виявлено на півночі Луганщини в районі Новопскова, Сватового та Троїцького. Найбільші значення додатних відхилень становили +0,6 і спостерігались у Новопскові та Сватовому, a у Троїцькому вони становили $+0,5$. На Донеччині найбільш помітний осередок додатних відхилень спостерігався на південному сході області в районі Волновахи $(+0,9)$ та Маріуполя $(+0,5)$. Осередок від'ємних відхилень середньої кількості випадків відкладень ожеледі знаходиться на території, що охоплює південь та центр Луганщини та схід Донеччини (район Луганська, Дар'ївки, Дебальцевого, Донецька та Амвросіївки). Встановлено, що значення від'ємних відхилень знаходяться в межах $-0,7 \ldots-1,2$. На жаль, на цій території відсутня інформація із середини 2014 р., тому немає надійної інформації щодо поточного стану випадків відкладень ожеледі у цьому регіоні.

У південному регіоні осередки додатних відхилень спостерігались на півночі Одеської області. Це південна периферія осередку додатних відхилень середньої кількості випадків відкладень ожеледі на території Вінницької області. Найбільше значення таких відхилень спостерігалось у районі Любашівки та становило $+0,6$. На південному заході Одещини також виявлено осередок додатних відхилень, проте незначних, а саме $+0,3$. На території інших південних областей величини додатних відхилень були ще більш незначними, а саме до $+0,1 \ldots+0,2$. Осередки від'ємних відхилень на території південних областей спостерігались на території Одеської області в районі Чорноморська $(-0,6)$, а також на півдні Миколаївщини в районі Очакова $(-0,7)$. На півночі Херсонщини розташований осередок від'ємних відхилень у районі Великої Олександрівки $(-0,8)$, а на сході 
спостерігається значний осередок таких відкладень у районі Асканії Нової $(-1,1)$ та Генічеська $(-1,7)$. Осередок на сході Херсонщини поєднується з осередком таких відхилень на Запоріжжі, який існує в районі Запоріжжя $(-0,6)$, Пришибу $(-0,9)$ та Ботієвого (рис. 1).

Грудень. Протягом грудня 2011-2019 рр. відносно 1981-2010 pp. осередки додатних відхилень середньої кількості випадків відкладень ожеледі спостерігаються на території північно-західних та західних областей. Основний осередок таких відхилень займає територію Житомирщини, східну частину Рівненщини, більшу частини Хмельниччини та Тернопільщини, Чернівецьку областьь та південний схід Івано-Франківщини. Крім того, окремий осередок таких відхилень знаходиться на північний схід від Львова (Кам'янка-Бузька). Ще один осередок таких відхилень охоплює південно-західну частину Львівщини в районі Турки та північно-західну частину Закарпаття в районі Нижніх Воріт i Плаю. Здебільшого величини додатних відхилень перебували у межах $+0,3 \ldots+0,4$. Найбільші значення додатних відхилень середньої кількості випадків відкладень ожеледі спостерігались у районі Овруча та Житомира $(+0,6)$, Кам'янки-Бузької та поблизу Турки $(+0,5$ та $+1,0$ відповідно), Шепетівки $(+0,5)$. На півдні Тернопільщині у Чорткові додатне відхилення становило $+0,8$, на крайньому південному заході Чернівецької області у Селятині воно становило $+0,6$. На Закарпатті у Нижніх Воротах та Плаю величина додатних відхилень становила $+1,2$. На окремих територіях поблизу осередків додатних відхилень спостерігалася стала ситуація, тобто середня кількість випадків із відкладеннями ожеледі майже не змінилась. Осередки від'ємних відхилень середньої кількості випадків відкладень ожеледі спостерігались на території низки областей, а саме Житомирщині в районі Коростеня $(-0,5)$, а також на Рівненщині та Волині з центром у районі Луцька $(-0,7)$. Цей осередок простягнувся на північ Тернопільщини в район Кремінця $(-0,5)$. На території Львівщини осередок таких відхилень спостерігається на північному заході в районі Рави-Руської (-0,7). На Івано-Франківщині осередок від’ємних відхилень відзначено в районі Долини та Івано-Франківська, де значення таких відхилень становили $-0,4$ та $-0,5$ відповідно. Частина цього осередку з незначними від'ємними відхиленнями спостерігалася в районі Нижнього Студеного (Закарпаття). Невеликий осередок від'ємних відкладень розташований на південному заході Закарпаття поблизу Берегового $(-0,5)$ та Міжгір'я.

На півночі та північному сході осередки додатних відхилень спостерігались на території Київщини (північ та північний захід), Чернігівщини (північ та центр), Сумщини (північ), Харківщини (північ та схід). На Київщині здебільшого переважають незначні величини 
додатних відхилень, а саме до $+0,2$. Найбільше значення таких відхилень становило $+0,4$ і спостерігалось у Вишгороді. На Чернігівщині додатні відхилення були дещо більшими, становлячи $+0,3 \ldots+0,4$, на півночі області у Сновську вони становили $+0,5$. На Сумщині осередок додатних відхилень знаходиться на півночі області в районі від Хутора Михайлівського до Глухова. Найбільше значення додатних відхилень становило $+0,6$ у Глухові. На Харківщині додатні відхилення спостерігаються на всій території області. Найбільш помітні осередки знаходяться на півночі Харківщини в районі Золочева, Богодухова та Коломака. Найбільші значення додатних відхилень у цьому осередку становлять $+0,6 \ldots+0,7$. На сході області спостерігається ще більш розповсюджений осередок доданих відкладень. Він охоплює територію від Великого Бурлуку до Лозової. Найбільші значення таких відхилень спостерігались у Комсомольському $(+0,9)$ та в Ізюмі $(+1,1)$. Загальний осередок додатних відкладень на Харківщині пов'язаний із полем додатних відхилень на території Полтавщини на заході та південному заході, а на сході - 3 полем додатних відхилень середньої кількості випадків відкладень ожеледі у східному регіоні країни. На деяких територіях Чернігівської та Сумської областей середня кількість випадків відкладень ожеледі не змінилась. Осередки від'ємних відхилень середньої кількості випадків відкладень ожеледі спостерігаються в низці областей. Один із найбільших спостерігається на значній частині Київщини південніше Києва. Найнижчі значення від'ємних відхилень спостерігались у Борисполі $(-1,1)$, Білій Церкві $(-0,6)$ та Миронівці $(-0,8)$. Частина цього осередку переходить на північному сході у Чернігівську область у бік Остра $(-0,3)$, а на півдні - в район півночі Черкащини у бік Канева $(-1,0)$. На території Сумщини спостерігаються два осередки від'ємних відкладень: один малопотужний у районі Конотопа $(-0,5)$ та Ромен, а інший більш чітко виражений поблизу Сум $(-1,0)$ та Лебедина $(-0,4)$. Зовсім незначний осередок від'ємних відхилень спостерігається на Харківщині в районі Краснограду.

На сході України осередки додатних відхилень середньої кількості випадків відкладень ожеледі розташовувались на території Луганщини та Донеччини. Розповсюдження додатних відхилень пов'язано з полем розповсюдження таких відхилень на території Харківщини та Дніпропетровщини. Додатні відхилення спостерігаються на території Луганщини. Їх основний осередок на Луганщині розташований на півночі області в районі Троїцького, Новопскова та Сватового. Найбільші значення додатних відхилень середньої кількості випадків відкладень ожеледі спостерігались у Новопскові $(+2,0)$ та у Сватовому. На решті території їх значення не перевищували $+0,3$. На Донеччині 
додатні відхилення середньої кількості випадків відкладень ожеледі спостерігаються на території західної та південно-західних частин області. Найбільш значними додатні відхилення виявились у Покровському, Волновасі та Маріуполі, які становили $+0,8,+1,8$ та $+1,0$ відповідно (рис. 1). Осередки від'ємних відхилень середньої кількості випадків відкладень ожеледі сконцентровані на півдні Луганщини та сході Донеччини. Там їх значення можуть сягати від $-1,0 \ldots-1,8$ на Луганщині до -2,5...-2,7 на Донеччині.

У центральному регіоні осередки додатних відхилень середньої кількості випадків відкладень ожеледі розташовувались на більшій частині Вінниччини, заходу півдня Черкащини, більшій частині Кіровоградщини, східній частині Полтавщини та Дніпропетровщини. На Вінниччині найбільш помітні осередки таких відхилень знаходяться в районі Вінниці та Жмеринки, а на південному сході - у Гайсині. Осередок додатних відкладень на Вінниччині поєднується з осередком таких відкладень на Черкащині та Кіровоградщині. На Черкащині центри осередків додатних відкладень спостерігаються в районі Жашкова, Сміли та Звенігородки. Вони становлять $+1,1,+0,9,+1,0$ відповідно. На Кіровоградщині значні додатні відхилення середньої кількості випадків відкладень ожеледі знаходяться переважно в центральній частині області та розповсюджуються 3 півночі на південь. Найбільш помітними центрами таких відхилень є Світловодськ $(+0,8)$, Новомиргород $(+0,9)$, Гайворон $(+1,1)$, Помічна $(+0,7)$, Долинська $(+0,7)$. На території Полтавщини додатні відхилення середньої кількості випадків відкладень ожеледі здебільшого перебували в межах до $+0,3$, проте на південному сході у Кобеляках додатне відхилення становило +1,3. На Дніпропетровщині здебільшого додатні відхилення спостерігались на сході області. Найбільші значення таких відхилень спостерігались у Комісарівці $(+0,9)$, Чаплиному $(+0,9)$ та Нікополі $(+1,1)$. Осередки від'ємних відхилень середньої кількості випадків відкладень ожеледі спостерігались на Вінниччині поблизу Хмільника $(-0,5)$, у Каневі $(-1,0)$ на Черкащині, на території Полтавщини в районі Веселого Подолу, на півдні Кіровоградщини у Бобринці $(-0,5)$, а також у Дніпрі $(-0,7)$.

На півдні країни осередки додатних відхилень середньої кількості відкладень ожеледі спостерігались на північному заході Одещини, півночі Миколаївщини (Первомайськ), північно-східній та південній частинах Херсонщини, північному заході та центрі Запоріжжя. Найбільш помітним був осередок таких відхилень у Первомайську $(+1,2)$, який пов'язаний із полем додатних відхилень на території Кіровоградщини, особливо на іiі півдні. На Херсонщині достатньо значні додатні відхилення спостерігаються на півночі та північному сході в районі Великої Олександрівки та Нової Каховки $(+0,9)$, а також 
на півдні у Бехтерах $(+1,2)$. На решті території області такі відхилення становлять $+0,2 \ldots+0,3$. Осередок додатних відхилень у районі Великої Олександрівки та Нової Каховки поєднується 3 осередком таких відхилень на території Запорізької області на їі півночі та заході. Найбільш помітні центри такого осередку знаходяться в районі Запоріжжя $(+0,6)$ та Мелітополя $(+0,7)$. На окремих частинах територій південного регіону спостерігаються ділянки, де середня кількість випадків відкладень ожеледі протягом 2011-2019 рр. відносно 19812010 рр. практично не змінилась. Така тенденція спостерігається в Одеській області на південному заході, на сході Миколаївщини, південному сході Херсонщини, у центральній частині Запоріжжя. Осередки від'ємних відхилень середньої кількості випадків відкладень ожеледі на півдні України спостерігаються на території Одеської області у напрямку від Любашівки $(-0,5)$ на північному сході на південь у район Роздільної $(-0,5)$ та Одеси, а також на крайньому південному заході області в Ізмаїлі $(-0,5)$. На Миколаївщині осередок від'ємних відхилень знаходиться на сході області в районі Баштанки $(-0,6)$ та поєднується 3 осередком подібних відхилень в районі Бобринця на Кіровоградщині. На Херсонщині осередок від'ємних відхилень зосереджений у районі Генічеська $(-0,7)$. На Запоріжжі осередок від'ємних відхилень простягнувся з центру області в районі Гуляйполя та Кирилівки на південь у бік Ботієвого. Значення відхилень у цьому осередку незначні, адже перебувають у межах $-0,2 \ldots-0,3$.

\section{2. Тенденції розповсюдження випадків відкладень ожеледі на території України протягом 2011-2019 рр. у весняні та осінні місяці порівняно з 1981-2010 pp.}

Березень. У березні в сучасний період відносно 30-річної норми 1981-2010 pр. на території північно-західних та західних областей України спостерігалось декілька осередків додатних відхилень середньої кількості випадків відкладень ожеледі. Загальний осередок таких відхилень розташований на території Рівненщини, Волині, Львівщини, Тернопільщини, західної частини Хмельниччини, Чернівецької області, півдня Івано-Франківщини та більшої частини Закарпаття. На цій території особливо виділяються окремі центри осередків додатних відхилень. Таким осередком $є$ осередок, який розташований на території Тернопільської області з центрами у Тернополі та Чорткові $(+0,6)$, в районі Львова $(+0,5)$, на Івано-Франківщині в районі Поржежевської $(+0,5)$, на Закарпатті на Плаю $(+0,7)$ та в Ужгороді $(+0,4)$. В цьому регіоні існують території, де середня кількість випадків із відкладеннями ожеледі не змінились. Вони спостерігались на сході Рівненщини, у 
центральній частині Волинської області, на більшій частині ІваноФранківщини, заході Чернівецької області та Закарпатті. Осередок від'ємних відхилень розповсюджувався майже на всю територію Житомирщини, Хмельниччини, північ Вінниччини та південний захід Київщини. Помітними центрами цього осередку були Коростень $(-0,5)$ та Нова Ушиця $(-0,6)$.

На півночі та північному сході країни осередки додатних відхилень середньої кількості випадків відкладень ожеледі спостерігались на півночі Чернігівщини (до $+0,2$ ) та Сумщини (Хутор Михайлівський $(+0,4))$. Цей осередок розповсюджувався на територію Харківщини та Полтавщину, а на схід та південь - у Донецький регіон. На Харківщині найбільш значні додатні відхилення середньої кількості випадків відкладень ожеледі спостерігались на більшій частині території області, а саме у Богодухові $(+0,8)$, Великому Бурлуці $(+0,7)$, Коломаку $(+0,7)$, Куп'янську $(+0,6)$, Ізюмі $(+0,7)$, Лозовій $(+0,8)$, особливо у Краснограді $(+0,9)$. Незначні осередки від'ємних значень спостерігались на півночі Київщини в районі Чорнобиля $(-0,3)$, на їі південному заході в районі Фастова $(-0,4)$, а також на Сумщині в районі Конотопу $(-0,3)$. На значній частині Київщини та Чернігівщини середня кількість випадків відкладень ожеледі майже не змінилась.

На сході країни у Донецькому регіоні осередок додатних відкхилень середньої кількості випадків відкладень ожеледі пов'язаний 3 їх розповсюдженням на території Харківщини та Полтавщини. Так, на території Луганщини основна локалізація найбільших значень таких відхилень зосереджена на півночі області в районі Троїцького $(+0,6)$, Новопскова $(+0,8)$, особливо Сватового $(+1,0)$. На решті території області, за винятком ії південної частини, величина додатних відхилень не перевищувала $+0,4$. На Донеччині осередок додатних відхилень займає північну, західну та південну частини області. Найбільш значні 3 додатних відхилень спостерігаються в Бахмуті (Артемівськ) $(+0,7)$, Красноармійську $(+1,1)$ та Волновасі $(+1,1)$. Осередок від'ємних відхилень, як і в решті місяців, займає південний схід, південь Луганщини та схід Донеччини.

У центральному регіоні осередок додатних відхилень спостерігається на території східної та південної частини Вінницької області з центром у Гайсині $(+0,5)$, а на решті території значення відхилень становлять до $+0,2 \ldots 0,3$. На Черкащині та Кіровоградщині більш менш помітні осередки додатних відхилень розташовані на території східної та південної частин Черкащини $(+0, \ldots+0,4)$, а також у східній та південній частинах Кіровоградщини, особливо в районі Знам'янки $(+0,6)$. На території Полтавщини осередок додатних відхилень середньої кількості випадків відкладень ожеледі пов'язаний 
iз розповсюдженням цих відхилень на території Харківщини. Додатні відхилення розповсюджені на території Полтавської області повсюди, але найбільш значними є в районі Лубен $(+0,8)$ та Полтави $(+0,7)$. На Дніпропетровщині найбільш помітні додатні відхилення спостерігались переважно на сході області, особливо в районі Павлограда $(+0,6)$ та Чаплиного $(+0,6)$. Осередок від'ємних відхилень спостерігався на території Кіровоградщини в районі Помічної $(-0,6)$.

У південних областях осередки додатних відхилень спостерігаються на території Миколаївської області в районі Первомайська $(+0,4)$, а також на сході області в районі Баштанки та Миколаєва $(+0,2 \ldots+0,3)$. На Херсонщині найбільші значення додатних відхилень становили на сході та півдні області в районі Нижніх Сірогоз та Нової Каховки $(+0,4 \ldots+0,5)$, а у Бехтерах вони складали $+1,0$. На Запоріжжі найбільші 3 додатних відхилень середньої кількості випадків відкладень ожеледі становили $+0,3 \ldots+0,4$ і спостерігались у районах Гуляйполя, Кирилівки, Мелітополя та Ботієвого (рис. 1). Незначний осередок від'ємних відхилень спостерігається в районі Пришибу $(-0,1)$.

Квітень. Протягом цього місяця відносно періоду 1981-2010 рр. на території України переважали незначні додатні відхилення середньої кількості випадків відкладень ожеледі $(+0,1 \ldots+0,3)$. Також на значній території України незалежно від регіону спостерігалася ситуація, за якої середня кількість випадків відкладень ожеледі відносно 19812010 рр. не змінилась. Осередок від'ємних відхилень спостерігається на території Херсонської області в районі Асканії Нової. Значення такого відхилення становить $-0,4$.

Жовтень. У жовтні на території України переважали додатні відхилення середньої кількості випадків відкладень ожеледі. Найбільші значення таких відхилень спостерігались на заході Львівщині в районі Рави-Руської $(+0,5)$, на півночі Хмельниччини у Ямполі $(+0,5)$, на півдні Івано-Франківщині на Пожежевській $(+0,6)$, на Вінниччині у Вінниці $(+0,5)$. На значній території України спостерігалась ситуація, за якої середня кількість випадків відкладень ожеледі не змінилась порівняно з періодом 1981-2010 рр. Випадки від’ємних відкладень були нечисленними та незначними $(-0,1 \ldots-0,2)$.

Листопад. Протягом листопада цього періоду на території України переважали осередки додатних відхилень середньої кількості відкладень ожеледі відносно 1981-2010 pр., особливо у північнозахідній та західній частинах.

На території північно-західних та західних областей значний за площею осередок таких відхилень розташовувався на території Житомирщини, Рівненщини, Волині, північній частині Львівщини, півночі та заході Хмельниччини, більшій частині Тернопільщини та 
Чернівецької області, півдні та заході Івано-Франківщини, більшій частині Закарпаття. На сході та півдні цей загальний осередок розповсюджується на територію західної та південної частини Київщини, захід Черкащини та Кіровоградщини, займає більшу частину Вінниччини та північ Одещини. Здебільшого значення додатних відхилень незначні, адже перебувають у межах $+0,2 \ldots+0,4$. На тлі цього осередку виділяються окремі більш інтенсивні осередки таких відхилень, а саме на Волині найбільш помітний осередок додатних відхилень знаходиться на півночі та північному заході в районі Світязя $(+0,6)$ та Любешова $(+0,5)$. На Житомирщині здебільшого переважають додатні відхилення зі значеннями $+0,3 \ldots+0,5$, проте в Овручі та Житомирі значення цих відхилень становлять $+0,7$ та $+0,9$ відповідно. На півночі Львівщини зустрічаються окремі осередки додатних відхилень зі значеннями $+0,3$ в районі Рави-Руської та Кам'янки-Бузької. Помітний осередок таких відхилень простягнувся 3 півночі Хмельницької та Тернопільської областей на південь у бік Чернівецької області та на захід на ІваноФранківщину. Найбільші значення додатних відхилень середньої кількості випадків відкладень ожеледі спостерігались у Ямполі $(+1,1)$, Тернополі $(+1,0)$, Чорткові $(+1,0)$, Чернівцях $(+0,7)$, Селятині $(+1,1)$, Долині $(+1,2)$. На Закарпатті найбільші значення додатних відхилень відзначено в районі Плаю $(+0,6)$ та в районі Ужгорода $(+0,5)$. На окремій території Львівщини середня кількість випадків відкладень ожеледі не змінилась порівняно з 1981-2010 рp. (рис. 1). Незначні осередки від'ємних відхилень спостерігались поблизу Львова та ІваноФранківська, становлячи -0,3 та -0,5 відповідно.

На півночі та північному сході країни спостерігався осередок додатних відхилень середньої кількості випадків відкладень ожеледі, який займає більшу частину Київщини, Чернігівщини та частину Сумщини, а також Харківщини. Цей осередок пов'язаний із полем додатних відхилень на північному заході в районі Київщини та поширюється на південь i південний схід у бік Черкащини, Кіровоградщини та Полтавщини. Найбільш розповсюдженими значеннями додатних відхилень є значення в межах $+0,1(+0,2) \ldots+0,3(+0,4)$. Найбільші значення таких відкладень для Київської області зафіксовано у Білій Церкві $(+0,4)$ та у Миронівці $(+0,5)$. На Чернігівщині значний осередок додатних відхилень розташований із півночі на південь від Сновська до Прилук. Найбільші значення таких відхилень відзначено у Сновську $(+1,4)$ та у Прилуках $(+0,6)$. На решті території осередка значення відхилень становили $+0,2 \ldots+0,4$. На Сумщині здебільшого переважали додатні відхилення в межах $+0,2 \ldots+0,3$. На Харківщині також здебільшого переважали незначні додатні відхилення, за винятком північної частини області, де в районі Золочева, Краснограду та Богодухова вони становили $+0,4$ у Золочіві та Краснограді, $+0,6$ у 
Богодухові. Незначний осередок від'ємних відхилень знаходився в районі Хутора Михайлівського. Найбільше значення від'ємного відхилення становило -0,4. Також незначний осередок від'ємних відхилень спостерігався в районі Сум $(-0,2)$.

На сході країни осередки додатних відхилень знаходяться на півночі Луганської області та півночі і заході Донеччини. Це осередки незначної інтенсивності. Лише в районах Новопскова, Сватового та Маріуполя вони становили $+0,3$. На території півночі та заходу Донеччини вони становили $+0,2$. Осередок від'ємних відхилень в цьому регіоні знаходиться на території півдня Луганщини та центральної і східної частин Донеччини. У ньому від'ємні відхилення становлять від -0,6 (Луганськ, Дар’ївка), до -0,8...-1,7 (Дебальцеве, Донецьк).

У центрі країни осередки додатних відхилень середньої кількості випадків відкладень ожеледі спостерігаються на території Вінницької, півночі Одеської, заході та сході Черкаської, більшої частини Кіровоградської та Полтавської областей, а також на окремих територіях Дніпропетровської області. Осередок на території Вінниччини займає більшу частину області у напрямку 3 півночі на південь. Цей осередок пов'язаний з осередком додатних відхилень на території Житомирщини. Основний центр осередку знаходиться в районі Вінниці $(+1,2)$ та в районі Гайсина $(+0,7)$. На решті території значення додатних відхилень становили $+0,4 \ldots+0,5$. На території Черкащини поле додатних відхилень середньої кількості випадків відкладень ожеледі пов'язане з такими відхиленнями на території Вінниччини, причому значення додатних відхилень середньої кількості випадків відкладень ожеледі знаходились у межах $+0,4 \ldots+0,5$, проте в районі Жашкова та Сміли їх значення становили $+0,6 \ldots+0,7$ відповідно. На Кіровоградщині осередок додатних відхилень пов'язаний із осередком таких відхилень на території Черкащини на півночі та осередком додатних відхилень на заході 3 території південно-східної частини Вінниччини. Тут здебільшого переважали додатні відхилення зі значеннями до $+0,4 \ldots+0,5$. Найбільше значення додатних відхилень становило $+0,8$ та спостерігалось у Помічній. На Дніпропетровщині додатні відхилення середньої кількості випадків із відкладеннями ожеледі виявились незначними та не перевищували $+0,2$, проте в районі Комісарівки (північний захід області) становили $+0,8$. Від’ємні відхилення середньої кількості випадків відкладень ожеледі зустрічались поодиноко, ї значення не перевищували $-0,2$.

На півдні країни осередки додатних відхилень спостерігаються на півночі Одеської області від Любашівки до Затишшя $(+0,2 \ldots+0,4)$, півночі Миколаївщини (Первомайськ $(+0,3))$, північному заході Херсонщини (Велика Олександрівка $(+0,3))$. Крім того, на Запоріжжі (південь та південний захід) спостерігався незначний осередок таких відхилень у 
районі Мелітополя та Ботієвого $(+0,6)$. На решті території кількість випадків відкладень ожеледі майже не змінилась (рис. 1). На більшій частині півдня України здебільшого переважали від'ємні відхилення середньої кількості випадків відкладень ожеледі. Вони займали значну територію регіону. На території Одещини виявляється осередок від'ємних відхилень із центром поблизу Роздільної $(-0,6)$. Загальний осередок таких відхилень протягається на схід у район Миколаївської області в район Миколаєва $(-0,2)$ та Очакова $(-0,4)$. На Херсонщині спостерігається осередок від'ємних відхилень, який охоплює південний схід області 3 центром у Асканії Новій $(-0,8)$. На Запоріжжі спостерігається незначний осередок від'ємних відхилень середньої кількості випадків відкладень ожеледі в районі Пришибу $(-0,3)$.

\section{ВИСНОВКИ}

Отже, протягом окремих місяців 2011-2019 рр. на території України відносно 1981-2010 рр. кількість випадків відкладень ожеледі найбільше збільшилась у січні, листопаді та грудні, про що свідчить значна кількість осередків додатних відхилень середньої кількості випадків відкладень ожеледі, а також площа, яку вони займають. Збільшення кількості випадків середньої кількості відкладень ожеледі виявилось найбільш показовим у січні.

У лютому разом із осередками додатних відхилень середньої кількості випадків відкладень ожеледі спостерігалась значна кількість осередків від'ємних, які займали значні площі на території областей України та перевищували площі додатних відхилень.

У березні збільшення кількості випадків відкладень ожеледі переважало на більшій частині України, проте найбільш помітним це було на північному сході та у східній частині центральних областей.

У квітні та жовтні на території України переважали незначні додатні відхилення середньої кількості випадків відкладень ожеледі, причому у жовтні найбільше.

Протягом листопада 2011-2019 рр. відносно 1981-2010 pp. осередки додатних відхилень загалом переважали та здебільшого спостерігались у північно-західному й західному регіонах. Осередки від'ємних відхилень спостерігалися в окремих частинах регіонів на Прикарпатті (південь Львівщини та Івано-Франківщина), півдні Харківщини, півночі Одещини та півдня Херсонщини. Також спостерігається значна територія (переважно центральний регіон), де середня кількість випадків відкладень ожеледі не змінилась.

У грудні помічена значна строкатість щодо розповсюдження осередків додатних або від'ємних відхилень відкладень ожеледі на території України. Характерною ознакою такого розповсюдження $\epsilon$ те, що осередки 
додатних відхилень середньої кількості відкладень ожеледі спостерігались майже в усіх областях, проте здебільшого були незначними за площею та спорадично розташованими, тоді як осередки від'ємних відхилень більш чітко прослідковувались на території областей та займали більшу площу.

\section{АНОТАЦІЯ}

Представлена стаття висвітлює особливості розповсюдження випадків відкладень ожеледі на території України протягом 2011-2019 рр. на сучасному етапі зміни клімату. Метою статті $\epsilon$ здійснення порівняння середньої кількості випадків відкладень ожеледі у різних регіонах країни відносно нового 30-річчя 1981-2010 pр., який рекомендовано ВМО для встановлення сучасних тенденцій у розповсюдженні метеовеличин та явищ на окремих територіях. Такий підхід було запроваджено для виявлення сучасних особливостей розподілу того чи іншого елементу з урахуванням різких та значних змін у кліматичній системі протягом останнього часу. Протягом окремих місяців зимового та перехідних сезонів року виявлено сучасну тенденцію розповсюдження відкладень ожеледі на території України. Встановлено осередки, де відбулись найбільші зміни у кількості випадків відкладень ожеледі в бік їх збільшення (додатні відхилення) або зменшення (від'ємні відхилення). Показано, що найбільші зміни відбуваються у зимові місяці, особливо у січні та грудні, а також наприкінці осені у листопаді.

\section{ЛІТЕРАТУРА}

1. Климат Украины / под ред. Г.Ф. Приходько, А.В. Ткаченко, В.Н. Бабиченко. Ленинград : Гидрометеоиздат, 1967. 413 с.

2. Природа Украинской ССР. Климат / под ред. К.Т. Логвинова, М.И. Щербаня. Киев : Наукова думка, 1984. 231 с.

3. Клімат України / за ред. В.М. Ліпінського, В.А. Дячука, В.М. Бабіченко. Київ : вид-во Раєвського, 2003. 343 с.

4. Опасные явления погоды на Украине / под ред. К.Т. Логвинова. Труды УкрНИГМИ. 1972. Вып. 110. 235 с.

5. Стихийные метеорологические явления на Украине и Молдавии / под ред. В.Н. Бабиченко. Ленинград : Гидрометеоиздат, 1991. 223 с.

6. Стихійні метеорологічні явища на території України за останне двадцятиріччя (1986-2005 рр.) / за ред. В.М. Ліпінського, В.І. Осадчого, В.М. Бабіченко. Київ : Ніка-Центр, 2006. 311 с.

7. Пясецька C.I. Тенденції в поширенні відкладень ожеледі на території України протягом 1991-2000 pp., 2001-2010 pp. на сучасному етапі зміни клімату (2011-2019 рр.) у місяці холодного періоду року та окремі місяці перехідних сезонів : колективна монографія. Scientific 
developments of Ukraine and EU in the area of natural sciences. P. 2. Wloclavek, Poland, 2020. C. 631-650. DOI: https://doi.org/10/30525/9789934-588-73-0/2/13.

\section{Information about the authors:}

Piasetska S. I.,

$\mathrm{PhD}$ of Geographical Sciences, Senior Research Fellow at the Department of Climate Research and Long-Term Weather Forecasting Ukrainian Hydrometeorological Institute of the State Emergency Service of Ukraine of the National Academy of Sciences of Ukraine 37, Nauki avenue, Kyiv, 03028, Ukraine

\section{Hrebeniuk N. P.,}

Junior Research Fellow at the Department of Climate Research and LongTerm Weather Forecasting Ukrainian Hydrometeorological Institute of the State Emergency Service of Ukraine of the National Academy of Sciences of Ukraine 37, Nauki avenue, Kyiv, 03028, Ukraine 